\title{
FURTHER OBSERVATION ON THE LACK OF ACTIVE UPTAKE SYSTEM FOR SUBSTANCE $P$ IN THE CENTRAL NERYOUS SYSTEM
}

\author{
Tomio SEGAWA, Yoshihiro NAKATA, Haruaki YAJIMA* \\ and Kouki KITAGAWA* \\ Department of Pharmacology, Institute of Pharmacentical Sciences, \\ Hiroshima University School of Medicine, Hiroshima 734, and \\ *Department of Manufacturing Chemistry, Faculty of Pharmaceutical Sciences, \\ Kyoto University, Sakyo-ku, Kyoto 606, Japan
}

Accepted April 25, 1977

\begin{abstract}
Crude mitochondrial $P_{2}$ fractions from bovine hypothalamus and substantia nigra, slices from rabbit spinal cord and mesenecphalon and glial fractions from rabbit brain were incubated with $\left[{ }^{3} \mathrm{H}\right]$-substance $P$ and the uptake was measured and compared with those for 5-HT and GABA. Substance $P$ was to some extent taken up into the fractions but this uptake was neither temperature nor time dependent and the pellet/ medium ratios werc less than 1 . Similar results were obtained in high potassium treated slices from rabbit mesencephalon. The rate of uptake for $\left.{ }^{3} \mathbf{H}\right]$-substance $\mathbf{P}$ increased linearly in proportion to the medium concentration, suggesting a non-saturable binding. These results, together with our previous observations provide strong evidence that nerve terminals and glial cells lack a temperature sensitive, active uptake system capable of terminating transmitter action of substance $P$ at the synapsc.
\end{abstract}

There is considerable evidence that substance $P$ is a neurotransmitter candidate in the mammalian central nervous system. Substance $P$ is observed in primary sensory neurons and nerve terminals in many brain areas (1) and is highly localized in subcellular organelles containing nerve ending particles (2). Substance P-like activity is released when the spinal cord isolated from newborn rats is stimulated clectrically or soaked in a high potassium medium (3). Synthetic substance $P$ exerts strong depolarizing action on the spinal motoneurons of the rat (4).

If substance $P$ does indeed act as a neurotransmitter, rapid inactivation at the site of action would be necessary. Benuck and Marks (5) have partially purified the enzyme responsible for inactivation of substance $\mathbf{P}$ in rat brain. However, extensive studies on the biogenic amines suggest that the uptake system, rather than the enzymatic inactivation may account for termination of transmittcr action at the synapse (6).

In a previous communication Segawa et al. (7) reported that uptake of labelled substance $P$ into crude mitochondrial fraction from rabbit brain and spinal cord differs from those of known putative transmitters. The amount of substance $P$ taken up at $37^{\circ} \mathrm{C}$ was almost the same as that taken up at $0^{\circ} \mathrm{C}$. The pellet/medium ratios scarcely exceed 1 . Furthermore, when the fraction incubated with labelled substance $\mathrm{P}$ was further subfractionated, the radioactivity was predominantly localized in the mitochondrial fraction. These results suggest that the uptake is not an active high affinity transport but rather a non-specific 
binding.

To confirm these observations the following experinents were performed. As marked regional differences in the uptake of the putative transmitter have been reported, the uptake of substance $\mathrm{P}$ was re-investigated in crude mitochondrial $\mathrm{P}_{2}$ fractions prepared from bovine hypothalamus and substantia nigra which are particularly rich in this substance $(2,8)$. Furthermore, since the high affinity uptake system has been demonstrated only with a low concentration of the transmitter in incubation medium, $P_{2}$ fraction was incubated with a low concentration of substance $P$. To exclude the possibility that substance $P$ nerve endings are fragile and are destroyed during homogenization and incubation we re-examined substance $P$ uptake into slices prepared from rabbit mesencephalon and spinal cord. The uptake into glial cells fraction was also investigated since it has bccome increasingly evident that glial cells may participate in the termination of certain transmitter actions at the synapse. For purposes of comparison, we studied the uptake of 5-hydroxytryptamine (6-HT) and $\gamma^{-}$ aminobutyric acid (CABA) since the cridence for their role as transmitters in the mammalian central nervous system is relatively good, if not conclusive.

\section{MATERIALS AND METHODS}

Substance P synthesized by the conventional method described in a previous paper (9), was labelled with tritium and purified as described previously (7). The specific activity is $1.31 \mathrm{Ci} /$ mmole. 4-Amino-n-[U-14 C]-butyric acid (224 mCi/mmole) and [ $\left.{ }^{3} \mathrm{H}\right]-5$-HT creatinine sulfate $(0.5 \mathrm{Ci} / \mathrm{mm}$ ole) were obtained from The Radiochemical Centre, Amersham.

\section{Preparation of crude mitochondrial $P_{2}$ fractions}

Bovine brain was obtained at a local slaughterhouse and hypothalamus and substantia nigra were minced and homogenized in 9 vol. of ice cold $0.32 \mathrm{M}$ sucrose using a Teflon pestle. The crude mitochondrial $P_{2}$ fraction was prepared by the method of Segawa and Kuruma (I0). Preparation of brain slices and glial cell enriched fractions

Rabbits weighing $1.9-2.6 \mathrm{~kg}$ of both sexes were decapitated and spinal cord and brain were rapidly removed. The spinal cord or midbrain excised from the whole brain was placed on wet (modified Krebs-Ringer solution) filter paper on ice, and was dissected with a razor blade into cubic slices of approximately $0.7 \mathrm{~mm}$ side. These slices were suspended in icecold modified Krebs-Ringer solution (11) bubbled previously with $95 \% \mathrm{O}_{2}-5 \% \mathrm{CO}_{2}$ for $10 \mathrm{~min}$ and were then allowed to stand for several min. The modified Krebs-Ringer solution was composed of $18 \mathrm{mM} \mathrm{NaCl}, 4.7 \mathrm{mM} \mathrm{KCl}, 1.9 \mathrm{~m} \mathrm{M} \mathrm{CaCl}, 0.5 \mathrm{mM} \mathrm{MgCl}_{2}, 25.0 \mathrm{mM} \mathrm{NaHCO}$ and $11.1 \mathrm{mM}$ glucose. After removing the supernatant by decantation the suspension was sieved through Nylon mesh with a pore size of 680 , am and the resulting filtrate was used for the study.

Fractions enriched in glial cells were prepared according to the method of Nagata et al. (12) with slight modification. The rabbit brain (without cerebellum) was immersed inmediately in ice-cold $10 \%$ Ficoll-basic buffer solution of $100 \mathrm{mM} \mathrm{KCl}$ in $10 \mathrm{mM}$ potassium phosphate buffer (pH 7.4) and then chopped with a razor blade. This preparation was then suspended in 2.5 vol. of ice-cold $10 \%$ Ficoll-buffer solution and sieved successively 
through Nylon mesh with progressively finer pore sizes: $800 \mu \mathrm{m}, 680 \mu \mathrm{m}, 430 \mu \mathrm{m}, 174 \mu \mathrm{m}$ and $82 \%$ To the filtrate an equal volume of $30 \%$ Ficoll in $10 \mathrm{mM}$ potassium phosphate buffer was added to make a final Ficoll concentration of $20 \%$. An aliquot of the filtered suspension was layered on the discontinuous sucrose $(50 \%)$-Ficoll $(30 \%)$ gradient and followed by $15 \%$ and $10 \%$ Ficoll solution. Centrifugation was carried out in a Hitachi Ultracentrifuge-55P with a SW-25 rotor at $41,000 \mathrm{~g}$ for $120 \mathrm{~min}$. The glial cells enriched fraction was aspirated, diluted with $20-30$ vol. of $0.32 \mathrm{M}$ sucrose and re-centrifuged at $11,500 \mathrm{~g}$ for $20 \mathrm{~min}$. The resulting pellets were suspended in $95 \% \mathrm{O}_{2}-5 \% \mathrm{CO}_{2}$ saturated modified Krebs-Ringer Solution.

Uptake of $\left[{ }^{3} \mathrm{H}\right]$-substance $\mathrm{P},\left[{ }^{3} \mathrm{H}\right]-5-\mathrm{HT}$ and $\left[{ }^{14} \mathrm{C}\right]$-GABA

Experiments were carried out by the modified method of Segawa et al. (7). Portions of tissue suspension containing $0.6-1.3 \mathrm{mg}$ protein $\left(\mathrm{P}_{2}\right), 10-20 \mathrm{mg}$ wet tissue (slices) or $0.5-1,0 \mathrm{mg}$ protein (glial cells) wcre transferred into $10 \mathrm{ml}$ polyethylene tubes. After preincubation for $10 \mathrm{~min}$ at $37^{\circ} \mathrm{C}, 0.1 \mathrm{ml}$ of $\left[{ }^{3} \mathrm{H}\right]$-substance $\mathrm{P},\left[{ }^{3} \mathrm{H}\right]-5-\mathrm{HT}$ or $\left[{ }^{1 \pm} \mathrm{C}\right]-\mathrm{GABA}$ (final concentrations are given in Table and Fig.) was added and a further incubation was carried out at $37^{\circ} \mathrm{C}$. At the end of the incubation period, $6 \mathrm{ml}$ of cold saline was added to the reaction mixture and centrifugation at $12,300 \mathrm{~g}$ was carricd out for $20 \mathrm{~min}$ at $4^{\circ} \mathrm{C}$ after which the supernatant fluid was collected. The pellet was re-suspended in $6 \mathrm{ml}$ of the cold saline solution and was re-centrifuged at $12,300 \mathrm{~g}$ for $20 \mathrm{~min}$. The washing was repeated. The radioactivity in the supernatant and the pellet was determined in a model 3320 Packard Tri-Carb liquid scintillation spectrometer and corrected for efficiency by external standardization.

\section{RESULTS}

Uptake of $\left[{ }^{3} H\right]-$ substance $P$ into crude mitochondrial $P_{2}$ fractions from bovine hypothalamts and substantia nigra

The results are presented in Fig. 1 and $T_{\text {abble }} 1$. When crude nitochondrial $P_{2}$ fractions from bovine hypothalamus or substantia nigra were incubaled with $1.46 \times 10^{-9} \mathrm{M}$ of $\left[{ }^{3} \mathrm{H}\right]-$ substance $P$ for 1,10 and 20 min, substance $P$ was to some extent taken up into the fractions. Initial rate of uptake was rapid. Thus, within $1 \mathrm{~min}$ after incubation, substance $P$ uptake reached a steady-state level which was maintained for $20 \mathrm{~min}$ (Fig. 1). However, since the fractions took up almost the same amount of substance $\mathrm{P}$ both at $0^{\circ} \mathrm{C}$ and $37^{\circ} \mathrm{C}$, the net uptake calculated by subtracting the value at $0^{\circ} \mathrm{C}$ from the value at $37^{\circ} \mathrm{C}$ was minute or nil. The pellet/medium ratios, calculated from the net uptake at $37^{\circ} \mathrm{C}$ were less than 1 (Table 1). These results are similar to those obtained with $2.3 \times 10^{-6}-2.3 \times 10^{-8} \mathrm{M}$ of $\left[{ }^{3} \mathrm{H}\right]$-substance $P$ in crude mitochondrial $P_{\mathfrak{z}}$ fractions from rabbit mesencephalon, diencephalon and spinal cord (7).

Uptake of $\left[{ }^{3} H\right]-$ strbstance $P$ and $\left[{ }^{3} H\right]-5-H T$ into rabbit brain slices

Slices prepared from rabbit spinal cord were incubated with $\left[{ }^{3} \mathrm{H}\right]$-substance $\mathrm{P}\left(7.5 \times 10^{-8}\right.$ M) for 1 and $10 \mathrm{~min}$ and the pellet/medium ratios were measured (Table 2). The results were similar to those found in crude mitochondrial $P_{2}$ fractions. The uptake was neither 


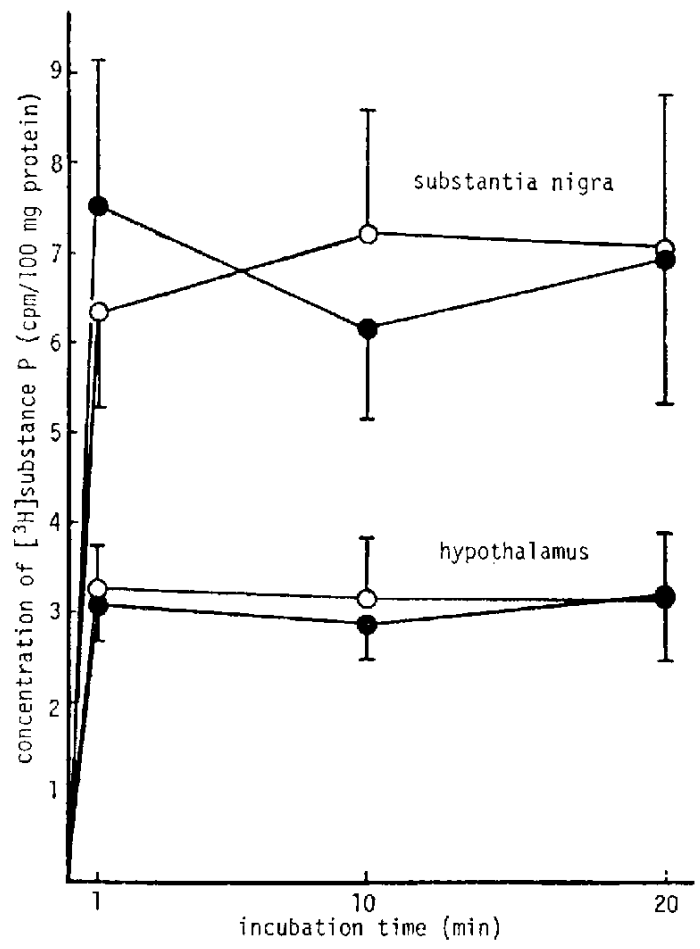

FK. 1. Tine course of [3] ${ }^{3}$-substance $P$ uptake into crude mitochondrial $P_{2}$ fractions from bovine hypothalamus and substantia nigra. The fractions are incubated for 1,10 and $20 \mathrm{~min}$ with $1.46: 10^{-4} \mathrm{M}\left[{ }^{3} \mathrm{H}\right]$-substance $\mathrm{P}$ at $0 \mathrm{C}(\mathrm{O})$ or $37 \mathrm{C}(\mathrm{C})$. Each point represents the mean of three determinations, vertical line indicates S.F.M.

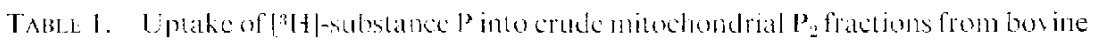
hypothalamus and substantia niglat

\begin{tabular}{|c|c|c|c|c|}
\hline \multirow{2}{*}{$\begin{array}{c}\text { Incubation } \\
\text { Time } \\
\text { (min) }\end{array}$} & \multicolumn{2}{|c|}{ Hypothalanous } & \multicolumn{2}{|c|}{ Substantia nigra } \\
\hline & $\begin{array}{c}\text { cpmimg protein } \\
(37 \mathrm{C}-0 \mathrm{C})\end{array}$ & Poilet medium & $\begin{array}{c}\text { cpming protein } \\
(37 \mathrm{C} 0 \mathrm{C}\end{array}$ & Pelletinedium \\
\hline 1 & $30: 15$ & 0.146 .0 .058 & 0 & 0 \\
\hline 10 & 43.17 & $0.211 \div 0.084$ & $102-37$ & $0.465: 0.185$ \\
\hline 20 & $18^{\prime}-7$ & $0.089 \cdot 0.035$ & $21 \ldots 9$ & $0.096: 0.042$ \\
\hline
\end{tabular}

Incubation procedure follows the description in methods. Pellet medium raties are calculated as epm in $100 \mathrm{mg}$ proteit per $\mathrm{cpm}$ in $1 \mathrm{ml}$ of modium. Concentration of [3H]-substance P is $1.46 .: 10^{-13} \mathrm{M}$. Values are presented as the mean ... S.L.M. of three decrminations.

temper blure nor time dependent and the pelletmedium ratios, calculated as emm in one gram of tissue per epm in one $\mathrm{ml}$ of medium were less than 1 . The uptake of [ $\left.{ }^{3} \mathrm{H}\right]-5-\mathrm{HT}$ is also presented in Table 2. A considerable uplake of $\left[{ }^{3} \mathrm{H}\right]-5-\mathrm{HT}$ occurred at $37 \mathrm{C}$, giving a

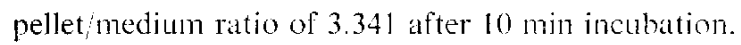

Uptake of [3 H]-substance $\mathrm{P}$ and [ $\left.{ }^{3} \mathrm{H}\right]-5-\mathrm{HT}$ into rabbit mesencephaton slices is shown 
TABLE 2. Uptake of $\left[{ }^{3} \mathrm{H}\right]$-substance $\mathrm{P}$ and $\left[{ }^{3} \mathrm{H}\right]-5-\mathrm{HT}$ into rabbit spinal cord slices

\begin{tabular}{|c|c|c|c|}
\hline \multirow{2}{*}{$\begin{array}{l}\text { Compound and } \\
\text { concentration }\end{array}$} & \multicolumn{2}{|c|}{ Incubation } & \multirow[t]{2}{*}{ Pellet/medium } \\
\hline & Temperature ("C) & Time $(\min )$ & \\
\hline \multirow{4}{*}{$\begin{array}{r}{\left[{ }^{3} \mathrm{H}\right] \text {-substance P }} \\
\left(7.5 \times 10^{-8} \mathrm{M}\right)\end{array}$} & 0 & 1 & $0.400 \pm 0.024$ \\
\hline & & 10 & $0.555 \pm 0.113$ \\
\hline & 37 & 1 & $0.559 \dashv 0.047$ \\
\hline & & 10 & $0.588+0.029$ \\
\hline \multirow{4}{*}{$\begin{array}{l}{\left[{ }^{3} \mathrm{H}\right]-5-\mathrm{HT}} \\
\quad\left(1 \times 10^{-7} \mathrm{M}\right)\end{array}$} & 0 & 1 & $0.353 \pm 0.015$ \\
\hline & & 10 & $0.448 \pm 0.048$ \\
\hline & & 1 & $0.775 \pm 0.075$ \\
\hline & 37 & 10 & $3.341-0.538$ \\
\hline
\end{tabular}

Incubation procedure follows the description in methods. Pellet/medium ratios are calculated as cpm in $1 \mathrm{~g}$ of tissuc per $\mathrm{cpm}$ in $1 \mathrm{ml}$ of medium. Values are presented as the mean $上$ S.E.M. of threc determinations.

TABLE 3. Uptake of $\left[{ }^{3} \mathrm{H}\right]-$ substance $\mathrm{P}$ and $\left[{ }^{3} \mathrm{H}\right]-5-\mathrm{HT}$ into rabbit mescncephalon slices

\begin{tabular}{cccc}
\hline Compound and & \multicolumn{2}{c}{ Incubation } & Pellet/medium \\
concentration & Temperature $\left({ }^{\circ} \mathrm{C}\right)$ & Time $(\mathrm{min})$ & \\
\hline $\begin{array}{c}\left.{ }^{3} \mathrm{H}\right] \text {-substance } \mathrm{P} \\
\left(7.5 \times 10^{-8} \mathrm{M}\right)\end{array}$ & 0 & 1 & $1.108 \pm 0.038$ \\
& & 10 & $1.172 \pm 0.386$ \\
& 37 & 1 & $1.070 \pm 0.105$ \\
& 0 & 10 & $0.873 \pm 0.166$ \\
{$\left[{ }^{3} \mathrm{H}\right]-5-\mathrm{HT}$} & & 1 & $0.387 \pm 0.055$ \\
$\left(1 \times 10^{-7} \mathrm{M}\right)$ & & 10 & $0.494 \pm 0.073$ \\
& 37 & 1 & $1.154 \pm 0.064$ \\
& & 10 & $5.884 \pm 0.437$ \\
\hline
\end{tabular}

Incubation procedure follows the description in methods. Pellet/medium ratios are calculated as $\mathrm{cpm}$ in $1 \mathrm{~g}$ of tissue per cpm in $1 \mathrm{ml}$ of medium. Values are prescnted as the mean $\perp$ S.E.M. of three determinations.

TABrl: 4. Uptake of $\left.{ }^{3} \mathrm{H}\right]$-substance $\mathrm{P}$ and [3H]-5-HT into high potassium treated rabbit mesencephalon slices

\begin{tabular}{|c|c|c|c|}
\hline \multirow{2}{*}{$\begin{array}{l}\text { Compound and } \\
\text { concentration }\end{array}$} & \multicolumn{2}{|c|}{ Incubation } & \multirow[t]{2}{*}{ Pellet/medium } \\
\hline & Temperature $\left({ }^{\circ} \mathrm{C}\right)$ & Time (min) & \\
\hline \multirow{4}{*}{$\begin{array}{r}{\left[{ }^{3} \mathrm{H}\right] \text {-substance } \mathrm{P}} \\
\left(7.5 \times 10^{-8} \mathrm{M}\right)\end{array}$} & & 1 & $1.024 \pm 0.074$ \\
\hline & 0 & 10 & $0.866 \pm 0.193$ \\
\hline & & 1 & $0.886 \div 0.117$ \\
\hline & 37 & 10 & $0.945+0.108$ \\
\hline \multirow{4}{*}{$\begin{array}{l}{\left[{ }^{3} \mathrm{H}\right]-5-\mathrm{HT}} \\
\quad\left(1 \times 10^{-7} \mathrm{M}\right)\end{array}$} & & 1 & $0.569 \pm 0.065$ \\
\hline & 0 & 10 & $0.737-\llcorner 0.046$ \\
\hline & & 1 & 2.020 - -0.194 \\
\hline & 37 & 10 & $10.615-0.614$ \\
\hline
\end{tabular}

The slices, preincubated with $40 \mathrm{mM} \mathrm{KCl}$ in modified Krebs-Ringer solution at $37^{\circ} \mathrm{C}$ for 10 min were incubated with $\left[{ }^{3} \mathrm{H}\right]-$ substance $\mathrm{P}$ or $\left[{ }^{3} \mathrm{H}\right]-5-\mathrm{HT}$. Pellet/medium ratios are calculated as $\mathrm{cpm}$ in $1 \mathrm{~g}$ of tissue per $\mathrm{cpm}$ in $1 \mathrm{ml}$ of mcdium. Values are presented as the mean:! S.E.M. of three determinations. 
in Table 3. The results here were similar to those obtained in spinal cord slices.

To exclude the possibility that the high concentration of endogenous substance $P$ in the preparation interferes with the uptake of exogenous substance P, rabbit mesencephalon slices were incubated at $37^{\circ} \mathrm{C}$ for $10 \mathrm{~min}$ in modified Krebs-Ringer solution containing $40 \mathrm{mM}$ $\mathrm{KCl}$ and thereafter, the slices were submitted to the uptake experiment as described above. As is shown in Table 4, the pellet/medium ratios for $\left[{ }^{3} \mathrm{H}\right]$-substance $\mathbf{P}$ were similar to, or somewhat lower than those in non-treated slices. On the other hand, when high potassium treated slices were incubated with $\left[{ }^{3} \mathrm{H}\right]-5-$ HT $\left(1 \times 10^{-7} \mathrm{M}\right)$ the pellet/medium ratio increased considerably at $37^{\circ} \mathrm{C}$, giving a value of 10.615 after 10 min incubation (Table 4).

To further characterize the uptake of substance $P$, the rate of initial uptake for $\left[{ }^{3} \mathrm{H}\right]$-substance $P$ from $3.75 \therefore 10^{-8} \mathrm{M}$ to $7.5 \times 10^{-6} \mathrm{M}$ was measured. Since the uptake was fast and appeared to reach a steadystate level within 1 min, substance $P$ uptake at 1 min was taken as a measure of initial uptake rate. The rute of uptake for $\left[{ }^{3} \mathrm{H}\right]$-substance $\mathrm{P}^{3}$ increased linearly in proportion to the medium con-

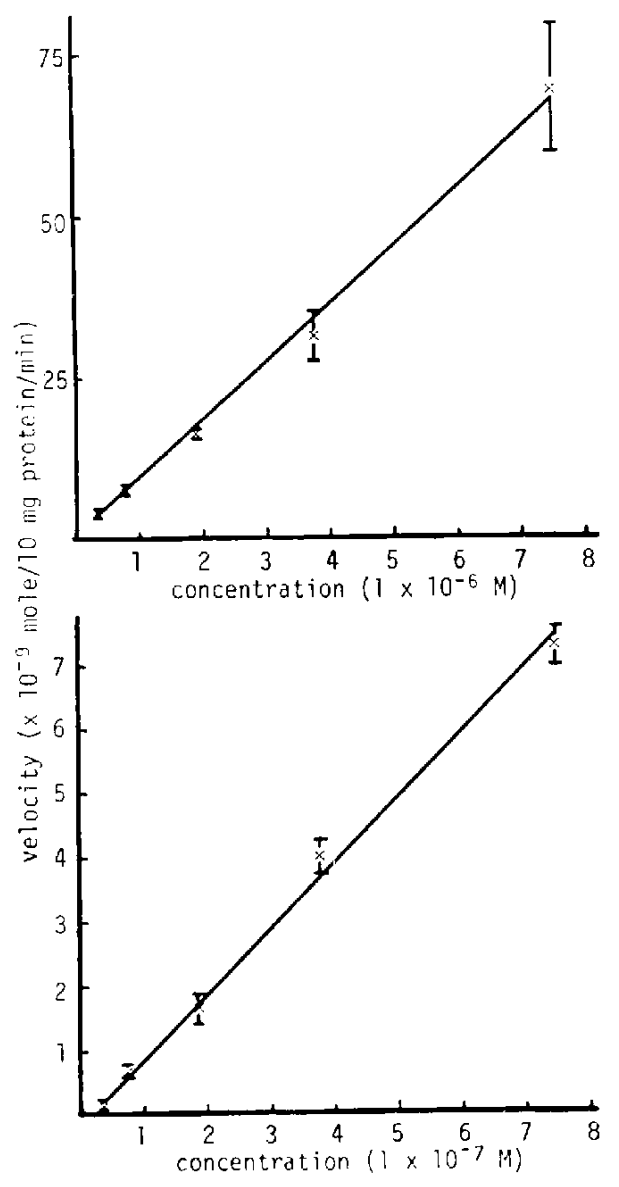

lik. 2. Velocity of $\left[{ }^{3} \mathrm{H}\right]-$ substance $\mathrm{P}$ uplake into rabbit mesencephalon slices. The slices were incubated for 1 min at $37 \mathrm{C}$ with $\left[{ }^{3} \mathrm{H}\right]$-substance $\mathrm{P}$ concentrations varying from $3.75 \therefore 10 \times$ to $7.5 \therefore 10 \times \mathrm{M}$. Each point represents the mean of three determinations, vertical line indicates S.E.M. centration, suggesting a non-saturable binding (Fig. 2).

Uptake of $\left[{ }^{3} H\right]-$ substance $P,\left[{ }^{3} H\right]-5-H T$ and $\left[{ }^{14} C\right]-G A B A$ into glial fractions from rabbit brain

As shown in Table 5, when glial flactions were incubated with $7.5 \therefore 10^{-9} \mathrm{M}$ of $\left[{ }^{3} \mathrm{H}\right]-$ substance $\mathrm{P}$, the pellet/mediun ratios were about 0.7 whereas with $7.5 \therefore 10^{-7} \mathrm{M}$ the ratios were 0.3 or less. The values presented in Table 5 for pellet/medium ratios were calculated as cpm in one $\mathrm{g}$ of pellet (wet weight) per epm in one $\mathrm{ml}$ of medium. In some experiments the extraparticulate space of the pellet was estimated by the inulin method and was found to be approx. $80 \%$. The ratios would therefore be considerably higher than those shown in Table 5. However, since the uptake was the same order of magnitude both at $0 \mathrm{C}$ and $37^{\circ} \mathrm{C}$, the net uptake was practically nil, irrespective as to whether or not this space correction 
TABLE 5. Uptake of $\left[{ }^{3} \mathrm{H}\right]$-substance $\mathrm{P},\left[{ }^{3} \mathrm{H}\right]-5-\mathrm{HT}$ and $\left[{ }^{14} \mathrm{H}\right]-\mathrm{GABA}$ into glial fractions from rabbit brain

\begin{tabular}{|c|c|c|c|}
\hline \multirow{2}{*}{$\begin{array}{l}\text { Compound and } \\
\text { concentration }\end{array}$} & \multicolumn{2}{|c|}{ Incubation } & \multirow[t]{2}{*}{ Pellet/medium } \\
\hline & Temperature $(\mathrm{C})$ & Time (min) & \\
\hline \multirow{4}{*}{$\begin{array}{r}{\left[{ }^{3} \mathrm{H}\right] \text {-substance } \mathrm{P}} \\
\left(7.5 \times 10^{-8} \mathrm{M}\right)\end{array}$} & & 1 & $0.684+0.105$ \\
\hline & 0 & 10 & $0.671-1-0.117$ \\
\hline & & 1 & $0.660+0.010$ \\
\hline & 37 & 10 & $0.793 \doteq 0.16 \mathrm{l}$ \\
\hline \multirow[t]{4}{*}{$\left(7.5 \times 10^{-7} \mathrm{M}\right)$} & & 1 & $0.214 \underline{-i-0.086}$ \\
\hline & 0 & 10 & $0.296 \pm 0.071$ \\
\hline & & 1 & $0.256-1=0.091$ \\
\hline & 37 & 10 & $0.312-1-0.079$ \\
\hline \multirow{4}{*}{$\begin{array}{l}{\left[{ }^{3} \mathrm{H}\right]-5-\mathrm{HT}} \\
\quad\left(1 \times 10^{-7} \mathrm{M}\right)\end{array}$} & & 1 & $0.641-0.112$ \\
\hline & 0 & 10 & $0.910 \div 0.191$ \\
\hline & & 1 & $1.463 \pm 0.296$ \\
\hline & 37 & 10 & $2.681 \pm 0.166$ \\
\hline \multirow{4}{*}{$\begin{array}{l}{\left[{ }^{[4} \mathrm{C}\right]-\mathrm{GABA}} \\
\quad\left(1 \times 10^{-7} \mathrm{M}\right)\end{array}$} & & 1 & $1.631 \pm 0.362$ \\
\hline & 0 & 10 & $2.125-0.472$ \\
\hline & & 1 & $5.541+0.692$ \\
\hline & 37 & 10 & $32.449 \pm 3.835$ \\
\hline
\end{tabular}

Incubation procedure follows the description in methods. Pellet/medium ratios are calculated as cpm in $1 \mathrm{~g}$ of pellet (wet weight) per cpm in $1 \mathrm{nul}$ of medium. Values are presented as the mean - S.E.M. of three determinations.

was applied. A considerable uptake into glial fractions was observed for $\left[{ }^{3} \mathrm{H}\right]-5-\mathrm{HT}$. In contrast to substance P and 5-HT, GABA was taken up much more actively into glial fractions at $37^{\circ} \mathrm{C}$, giving a pellet/medium ratio of 32 after a $10 \mathrm{~min}$ incubation.

\section{DISCUSSION}

Crude mitochondrial $P_{2}$ fractions from substance $P$ enriched brain areas such as the hypothalamus and substantia nigra were incubated with a low concentration of substance $P$. The results were almost the same as those obtained in a previous study (7), in which $P_{\text {: }}$ fractions from mesencephalon, diencephalon and spinal cord were incubated with relatively high concentrations of substance $P$. Therefore, active uptake of substance $P$ could not be demonstrated even in nerve terminals which contain a high concentration of endogenous substance $P$.

Since studies with brain slices have an advantage over those with synaptosomes in good preservation of tissue during preparation and incubation, we carried out similar uptake experinents with slices from rabbit mesencephalon and spinal cord. The existence of an efficient uptake mechanism for substance $P$ could not be demonstrated.

Uptake experiments with high potassium treated slices gave similar results. Endogenous substance $P$ can be released by high potassium from isolated nerve-endings $(13,14)$ and the spinal cord (15) in vitro, therefore the possibility could be excluded that the high concentration of endogenous substance $P$ in preparations interfereed with the uptake of cxogenous 
substance P.

Kinetic analysis of substance $\mathrm{P}$ uptake into rabbit mesencephalon slices indicated that the uptake is a non-saturable binding. The precise cellular site and the nature of substance $P$ uptake (or binding) remain to be elucidated. In a previous paper (7) we reported that when crude mitochondrial $P_{2}$ fraction was incubated with substance $P$, only a small amount of the substance was found to be associated with synaptosomes. Therefore, a non-specific binding of substance $P$ by cellular components other than nerve endings may account for the pellet/medium ratios observed in this experiment.

Henn and Hamberger (16), Sellström and Hamberger (17) observed that GABA could be accumulated much more actively by glial cell fraction than by synaptosomal or neuronal fraction. These authors suggested that a certain glial cell is actively concerned with the removal of GABA from the extracellular space that surrounds neurons. In the present study, with substance $P$, glial uptake was extremely low with a pellet/medium ratio of $0.3-0.7$. Therefore, it is improbable that glial cells contribute to the termination of transmitter action of substance $P$.

In summary, the present results, together with our previous findings provide strong evidence that nerve terminals and glial cells lack a temperature sensitive, active uptake system capable of terminating transmitter action of substance $P$ at the synapse. While preparing this manuscript, Iversen ct al. (13) reported similar findings that rat brain slices do not take up substance $P$, though the concentration employed in their experiment was considerably high $\left(10^{-5}-10^{-7} \mathrm{M}\right)$.

Acknowledgements: This work was supported in part by grant No. 048201 for the rescarch of science from the Department of Education, Science and Culture, Japan. Thanks are due to the staff of Shinloihi Co., Ltd., Kamakura, Japan for irradiation of substance P, and Sumitomo Chemical Co., Takarazuka, Japan, for aid in purilying $\left[{ }^{3} \mathrm{H}\right]$-substance P.

\section{REFERENCES}

1) Höktlet, T., KIII.RTI, J.O., Nilsson, G. ANI, PIRNow, B. : Scichle' 190, 889 (1975)

2) DUfFy, M.J., Mlliat.l, 1). AND Puwlit, D.: J. Neurochem. 25, 305 (1975)

3) Otuska, M.: Japan. J. Pharmacol. 26, Suppl. 12P (1976)

4) Konishi, S. Avd Otsuka, M.: Nature 252, 734 (1974)

5) BenUCK, M. AND Marks, N.: Biochem. biophis. Res. Commm. 65, 153 (1975)

6) Ben.vet, J.P., Mulder, A.H. AND SNyder, S.H.: Life Sci. 15, 1045 (1974)

7) Segawa, T., Naknta, Y., Nakamura, K., Yajma, H. and Kitagawa, K.: Japam. I. Pharmacol. 26, 757 (1976)

8) Powell, D., Lelman, S., Trfgilak, G.W., Niall, H.D. and Potts, J.T.: Nalure 241, 252 (1973)

9) Yamma, H., Kilngawa, K. and Siciniva, T.: (7km. Pham. Bull. 21, 2500 (1973)

10) Sicinwa, T. ANd Kiruma, I.; J. Phamm. Phammacol. 20, 320 (1968)

11) Nomura, Y., Tanaka, Y. and Segawa, T.: Brgin Res. 100, 705 (1975)

12) Nagata, Y., Mikoshiba, K. and Tsukadn, Y.: J. Neurochem. 22, 493 (1974)

13) Iversen, L.L., Jessell, T. ANd Kavazawa, I.: Nature 264, 81 (1976)

14) SCHENKer, C., MOR7, F.A. ANd Lhiman, S.E.: Nature 264, 790 (1976)

15) Otscka, M. And Konishi, S.: Natme 264, 83 (1976)

16) Heni, F.A. and Hawberger, A.: Prece hati. Acad. Sci. 68, 2682 (1971)

17) Selisirij, A. And Hambrrger, A. : J. Newochem. 24. 847 (1976) 